\title{
Dolomitization in Campanian Oil Shale Rocks from South-Western Jordan
}

\author{
Hani M. Alnawafleh'1, Khalid E. Tarawneh'2, Hani N. Khoury'3, Nafeth A. Abdelhadi', \\ Osama Y. Shakkoury5, Reyad A. Dwairi', Mazen N. Amaireh6 \\ ${ }^{1}$ Faculty of Engineering, Al-Hussein Bin Talal University, Ma'an, Jordan \\ ${ }^{2}$ Faculty of Engineering, Isra University, Amman, Jordan \\ ${ }^{3}$ Department of Geology, The University of Jordan, Amman, Jordan \\ ${ }^{4}$ Faculty of Engineering Technology, Al Balqa Applied University, Salt, Jordan \\ ${ }^{5}$ Natural Resources Authority, Amman, Jordan \\ ${ }^{6}$ Faculty of Engineering, Tafila Technical University, Tafila, Jordan \\ Email: hanialnawafleh@ahu.edu.jo
}

Received 23 August 2015; accepted 23 October 2015; published 26 October 2015

Copyright (C) 2015 by authors and Scientific Research Publishing Inc.

This work is licensed under the Creative Commons Attribution International License (CC BY). http://creativecommons.org/licenses/by/4.0/

\section{c) (i) Open Access}

\section{Abstract}

This work represents the first detailed study of an oil shale (OS) section from the Upper Campanian Amman Silicified Limestone (ASL) Formation in south-western part of Jordan. More than five meters of oil shale have been recorded. Using the petrography and geochemistry, this study aims to focus on such non-conventional types of oil shale rocks in Jordan and to shed some light on their composition and formational environment. Unlike oil shale from Maastrichtian to early Tertiary, this type of oil shale is highly dolomitized. The dolomite is diagenetic in origin. This oil shale type contains considerable amount of $\mathrm{OM}$ and remarkably enriched in some trace elements and shows quite low sulfur content. Results suggest that the formation of dolomite appears to be limited by the rate of organic matter oxidation.

\section{Keywords}

Jordan, Oil Shale, Dolomitization, Campanian

\section{Introduction}

Jordan has huge oil shale (OS) resource and considered one of the world leading countries in its OS potential deposits. More than 24 deposits are recorded [1]. The well-known Jordanian OS belongs to the upper cretaceous and lower tertiary formations [2]. The Jordanian OS is generally not exposed. Previous work conducted on Jor- 
danian OS is based mainly upon shallow boreholes and limited OS outcrops. Previous work and OS exploration in Jordan have focused on Upper Cretaceous OS from Muwaqqar Chalk Marl formation (MCM) (e.g. [3]-[8]). The OS from MCM formation is bituminous limestone [8]. At Wadi Al-Bustan, south-western corner of Jordan (Figure 1 and Figure 2), the OS is found in two stratigraphical levels. The upper (younger) level is that of MCM formation (Figure 2(a)) from Maastrchtian-Paleocene [2]. Full Petrographic and geochemical characterization of this OS type is found in Alnawafleh [8] and later papers by the same author (e.g. [9] [10]). The lower level (older) (Figure 2(b)), which is bituminous dolomitic limestone, is a part of upper Campanian Amman Silicified Limestone (ASL) Formation [2].

The ASL formation is related to the Late Cretaceous Belqa Group. Jordan was flooded during the Late Cretaceous and the shallow marine sediments of the Belqa Group were deposited [11]. The age of the ASL Formation is latest Cretaceous (Campanian-early Maastrichtian) [12]. Its thickness varies from 30 to $100 \mathrm{~m} \mathrm{[13]} \mathrm{[14].} \mathrm{The}$ base of this formation is defined below the first massive thick-bedded chert and above the marly chalks or silts/sands of the Wadi Umm Ghudran/Fassua Formation [15].

Dolomite is generally associated with sedimentary limestone. As a mineral, dolomite is common in ancient marine and terrestrial deposits [16]. Dolomite is found in wide range of formational setting [17]. Theories re-

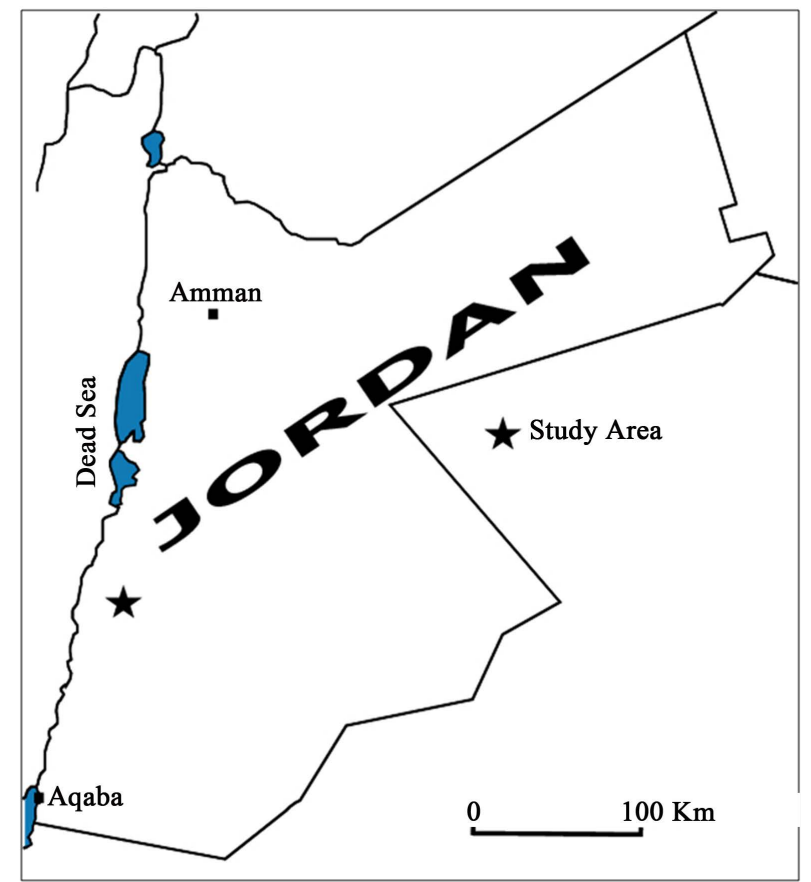

Figure 1. Location of Wadi Al-Bustan (study area).

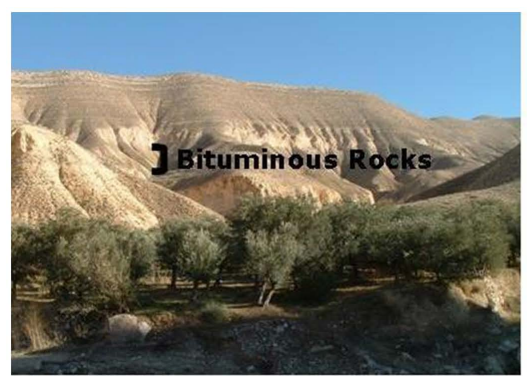

(a)



(b)

Figure 2. Oil shale surface exposures in Wadi Al-Bustan, S-W of Jordan. (a) Oil shale (bituminous rocks) exposure from Muwaqqar Chalk Marl Formation; (b) Close view of oil shale from Amman Silicified Limestone Formation. 
lated to dolomite formation are continued to evolve and many modes of dolomite origins are proposed. Based on their mode of formation, dolomites can be broadly divided into primary and secondary dolomites [18]. In Jordan, dolomite can be found in the Burj Dolomite-Shale Formation of Cambrian age and in upper cretaceous Naur, Hummar and Wadi Es-sir formations [19].

Literature deals with dolomitization in OS are quite limited. It is the purpose of this paper to understand the geologic characteristics and the genesis of dolomitized OS rocks from Jordan. The geochemical parameters discussed here are based on the various analyses results on OS surface outcrop samples from the bituminous dolomitic limestone section of the upper Campanian ASL Formation.

\section{Geologic Setting}

Jordan's OS from Campanian age is rarely referred to in literature. More attention has been given to that OS of the Muwaqqar Chalk Marl Formation. The OS from Campanian age is related to Amman Silicified Limestone Formation (ASL). These OS beds can easily be traced in the field as they are exposed in some wadis like Wadi Al-Bustan in Ash-Shoubak area. Amman Silicified Limestone Formation is easily traced across the country. This formation is characterized by cliff forming, massive chert beds overlaying the Wadi Umm Ghudran/Fassua Formation [15]. In South and Southeast Jordan, the deposition took place under marginal marine conditions with increased content of siliciclastic deposits [15]. Shallow near-shore environment for chert beds of this formation was concluded by Abed and Kraishan [20]. More information about the genesis of this formation is found in Abu Jaber et al. [13]. They reported that the ASL Formation was deposited on a shallow carbonate platform along the fringes of the Tethyan seaway. The stratigraphic column of ASL Formation within the studied area is shown in Figure 3.

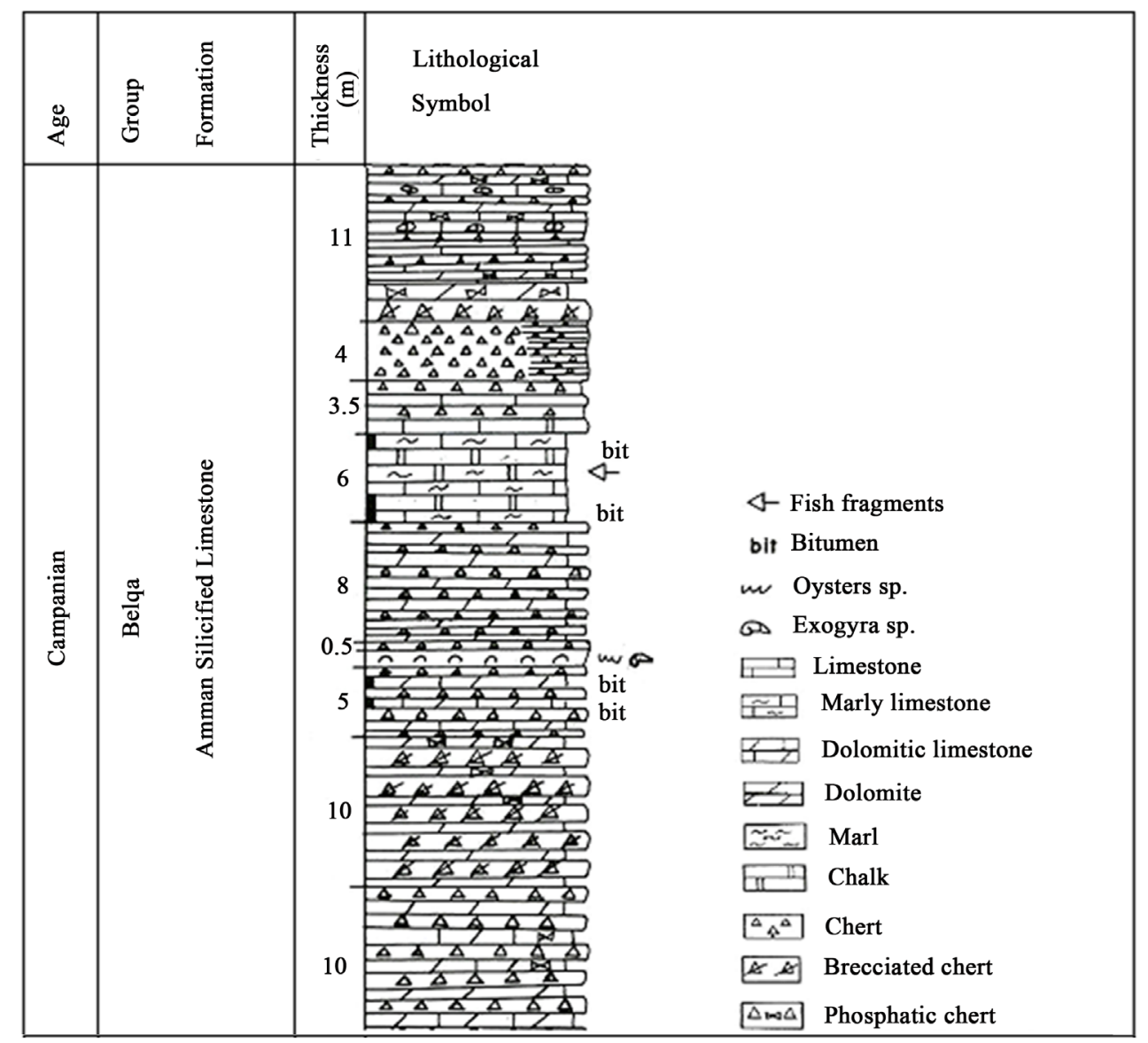

Figure 3. Lithologic column of Amman Silicified Limestone Formation in the study area. Modified from Barjous [36]. 
The formational framework of the Jordanian OS has been investigated by many researchers over the last four decades (e.g. [3] [4] [6] [8] [21]-[26]).There are several scenarios about the formation of Jordanian oil shales. These scenarios are combination of paleoclimatic, paleogeographic and paleotectonic factors. Recent biostratigraphic and petrographic studies on Upper Cretaceous-Eocene OS from Jordan have reached to similar results on the formational and controlling factors that have been reported and discussed previously by Alnawafleh [8] (e.g. [27]-[31]). In central Jordan, oil shale deposited in synclinal basins [3]. During the late Cretaceous period, the eastern Mediterranean formed part of the southern broad shallow epeiric shelf of the Tethys Ocean [15]. The sea-floor of the eastern Mediterranean was not topographically smooth but consisted of basins and swells [12]. These structures are believed to be resulted from the late cretaceous major tectonic pulse of the Syrian Arc fold belt [32]. With the areas covered by the Syrian Arc, the basins and swells are folded whereas in Jordan such structures are not folded [33] indicates the importance of the sea-floor bathymetry as a controlling factor of the upper cretaceous sedimentation in the region including Jordan's OS. Regional sea-level fluctuations of Late Cretaceous have played a major role in the deposition of OS in Jordan [8] [29]. The high productivity due to upwelling currents along the shelf edge and the anoxic bottom water conditions are major controlling factors in OS formation [4] [8] [34]. It is important to mention that some parts of OS in central Jordan have been pyrometamorphosed to marble [35].

\section{Field Work and Sampling}

Twelve samples were collected from the OS section that exposed at the base of Wadi Al-Bustan north of Ash-Shoubak area in south-western part of Jordan (Figure 1). The field observations show that this OS section is made of irregular rhythmic repetition of pale and dark bands of fine-grained mudstone. Nearly 5.5 meters were recorded and sampled. Oil shale section varies in hardness and occasionally fractured. The lower part is almost rich in shell fragments and fossil debris and biogenic material and contains some coarse concretion particles (biogenic debris or dolomitic lumps) and reveals sugary texture. Some bands in this section have distinguished bituminous smell. The OS in this section is overlain by marl and chert bands and underlain by phosphorite beds at the bottom.

\section{Experimental Work and Methodology}

Each sample was divided into three parts. One is saved as archive sample. The second was cut to prepare thin section for microscopic inspection. Twelve oil shale thin sections were prepared at the laboratories of Natural Resources Authority (NRA), Jordan. Half of each thin section was stained using staining test solution (Alizarin Red S) and then studied using the polarizing microscope. Photomicrographs of each OS type were taken using digital camera type Canon Power Shot S70. The third part of each sample was crushed by a crushing machine then further reduced down to monomineralic particles by vibrating agate ball mills. All samples were analyzed by carbon determinator (thermal conductivity detector) to indirectly estimate the quantity of organic matter in each sample. Total sulfur content (S wt\%) in four selected samples was determined using the multi EA®200 element analyzer available at NRA. Those samples have been tested for their oil shale retorting properties via Fischer Assay apparatus available at the NRA that determines oil, water, spent shale and gas loss in OS samples according to ISO 647 by thermal cracking method. Quantitative analysis of major oxides and trace elements was performed using X-Ray Fluorescence Spectrometer (XRF).

\section{Results and Discussion}

\subsection{Organic Matter Distribution}

Organic matter distribution is indicated from the distribution of total organic carbon (TOC) in the studied section. The TOC $\times 1.22$ is commonly equated to total organic matter (TOM). The resulting TOM is approximate because the 1.22 factor assumes certain amounts of oxygen, nitrogen, and sulfur is present [37]. The TOC in the studied oil shale section ranges from $3.62 \%$ to $20.57 \%$, therefore, the approximate TOM ranges from $4.42 \%$ to $25.10 \%$ respectively. The OS in some bands is of good quality as indicated from quite high values of TOM. Figure 4 shows a rapid transition from organic-rich to organic-depleted and inverse relationship between TOC and total inorganic carbon (TIC). The approximate TOM in this type of OS is within the range of Maastrichtian OS type reported from Jordan and adjacent areas (e.g. [5] [8] [9] [38]). 


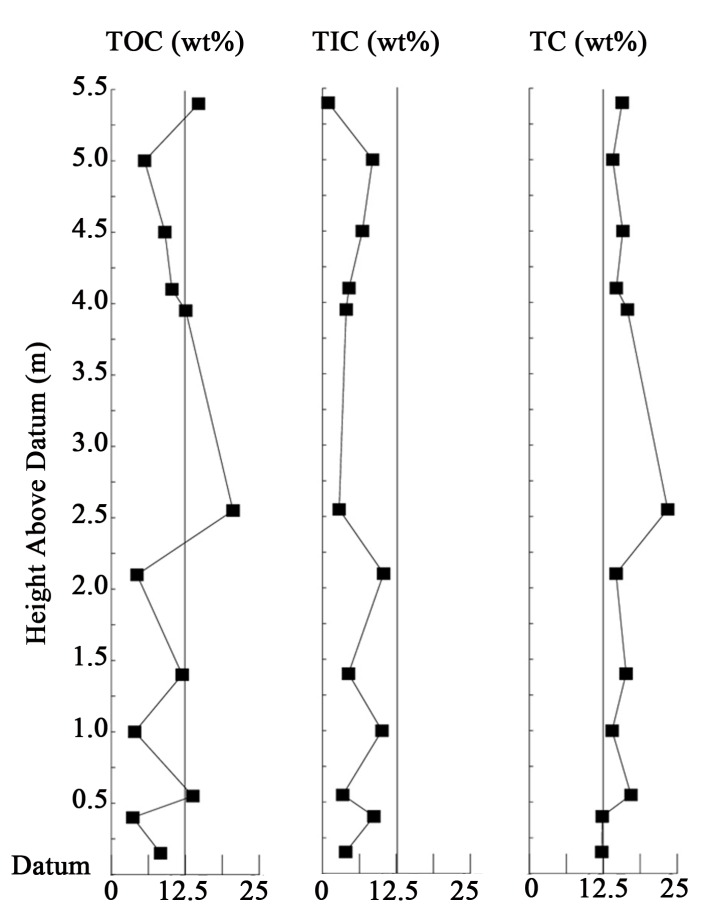

Figure 4. Depth profiles illustrate TOC distribution in the studied oil shale section.

\subsection{Mineralogical and Textural Change}

Figure 5 illustrates the prepared OS thin sections in relation to their TOC content. Generally, dark samples are TOC-rich and pale samples are TOC-depleted.

Under transmitted white light microscope, the TOC-depleted samples (Figure 6) have coarse crystalline dolomite mosaic texture. Dolomite grains are euhedral rhombs and idiomorphic. Samples show cross-cut relic microfabrics of the original carbonate with coarse replacement dolomite, carbonate overgrowth and intercrystalline porosity. The TOC-rich bands (Figure 6) are more laminated, composed of productivity derived and authigenic components. Samples show carbonate shell dissolution. This type contains more phosphatic particles and detrital grains. Such textural changes from TOC-rich bands to TOC-depleted bands suggest complex diagenetic history and indicate that the diagenetic processes have played a major role in the formation of this type of OS. The diagenesis is widely reported as a major factor controlled the formation of Upper Cretaceous rocks in region ([8] [39] [40], among many others).

The XRD analysis results for selected OS samples relative to their TOC content is shown in Figure 7. Based on relative XRD high peak data, OS samples shows major dolomite mineral phase. It is very obvious in TOCdepleted samples. The dolomatic content in high-TOC OS sample is lower than those of low-TOC samples. In addition to calcite, the highest TOC sample has minor quantities of quartz and traces of phosphate as fluorapatite, hematite, smectite and kaolinite. The later clay fraction is found only in TOC-rich samples. This suggests contribution terrigenous input. Combination the results of OS petrography with that of OS mineralogy and TOC content distribution, all suggest that there is a link between the OM content and dolomite formation. In other words, the formation of dolomite could be limited by OM content as the dolomite content decreases with increase of OM content. Dolomite decrease is associated with increase of calcite and productivity derived materials.

\subsection{Oil Shale Geochemistry}

The chemistry of OS section relative to the TOC content is illustrated in Figure 8 and Figure 9 respectively. Detail on origin, productivity, bottom water conditions and even climate can be inferred from the distribution of major elements oxides in addition to that of minor elements. Carbonate profiles (Figure 8) show negative trend 

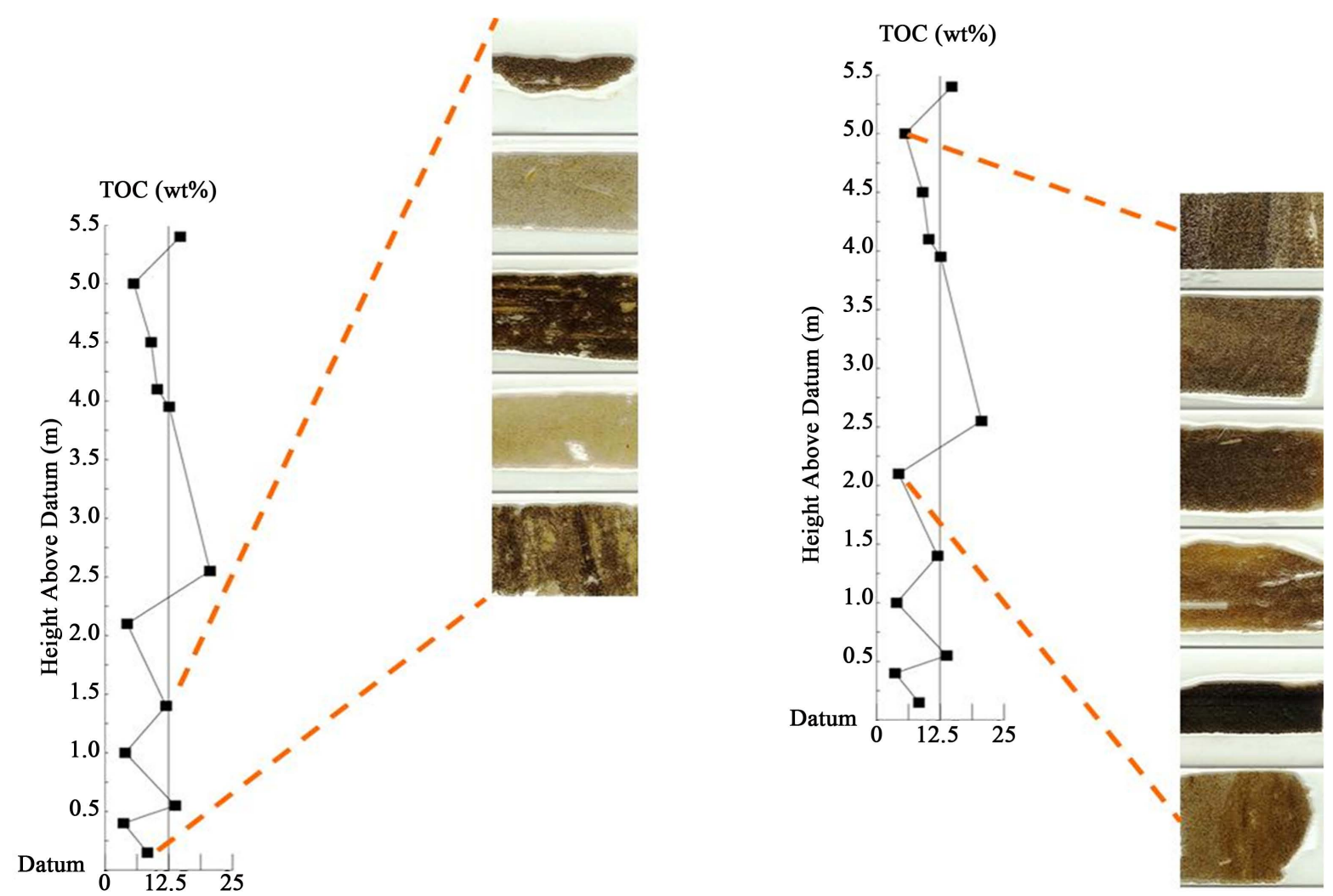

Figure 5. The studied oil shale samples (thin sections) in relation to their TOC content.

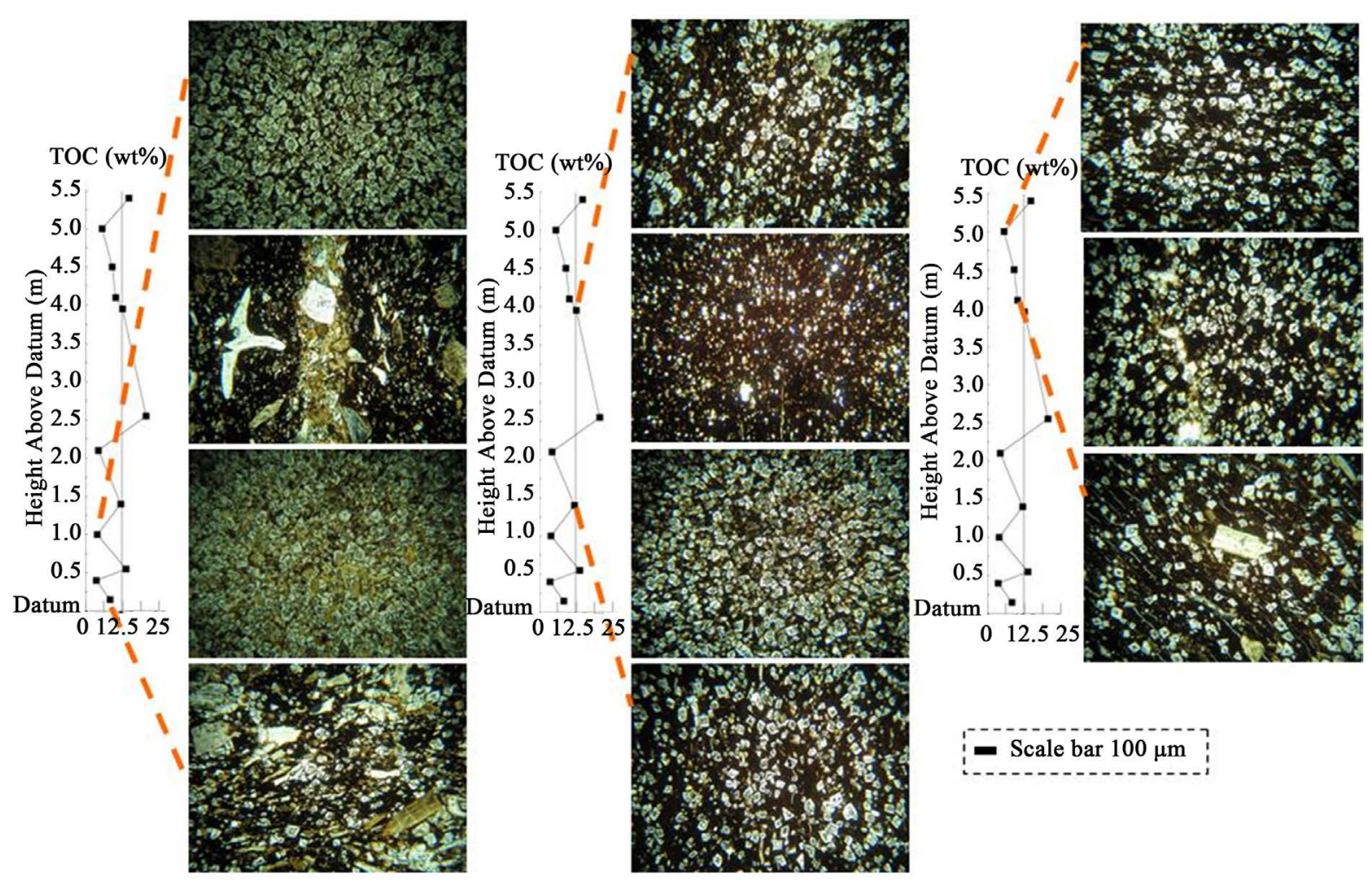

Figure 6. Texture of all studied oil shale samples under TWLM. 


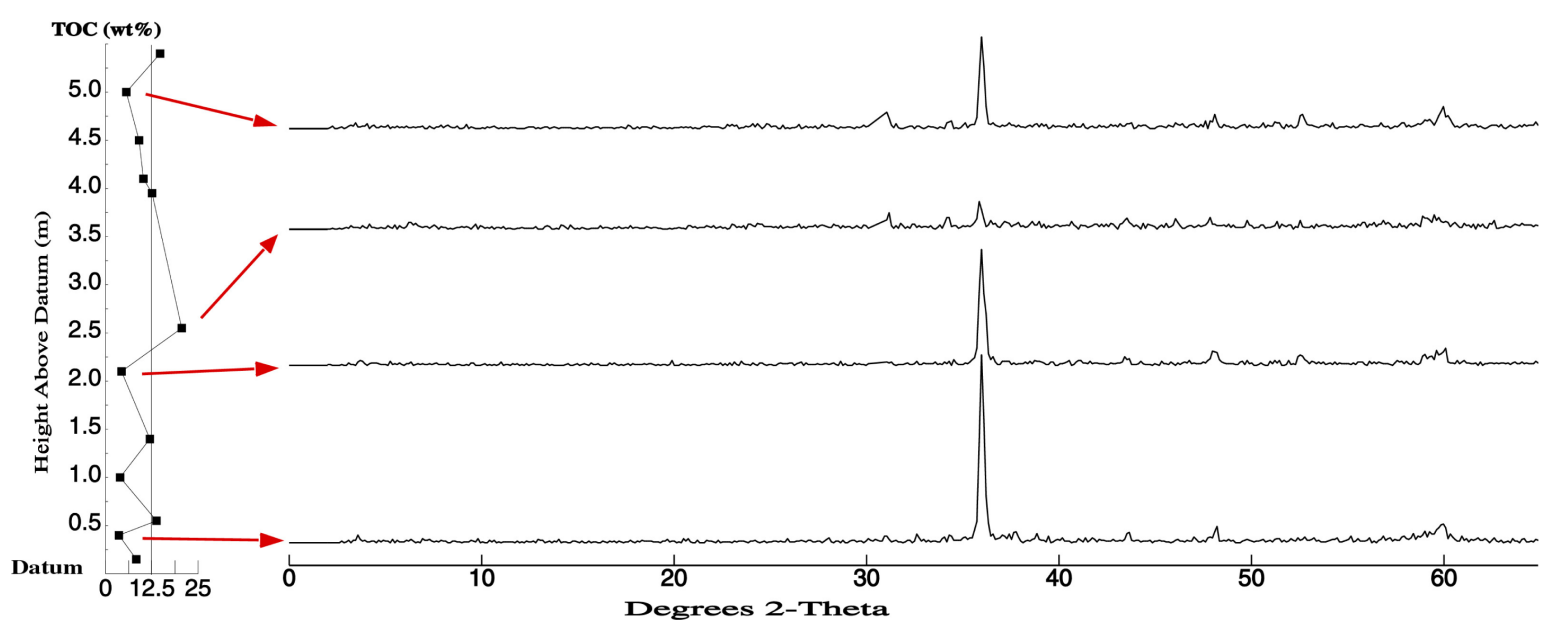

Figure 7. A series of XRD diffractograms for the studied oil shale samples in relation to their TOC content.
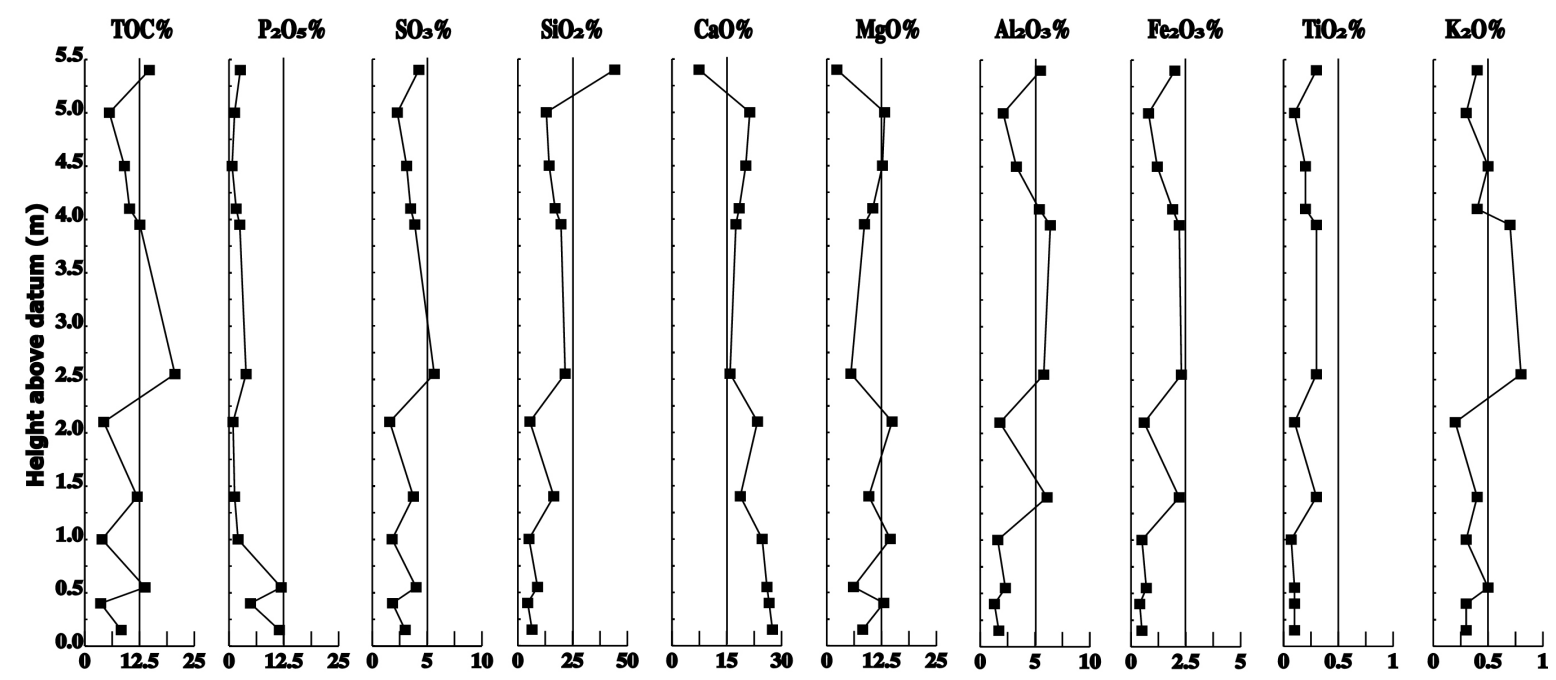

Figure 8. Depth profiles illustrate the distribution of major elements oxides.

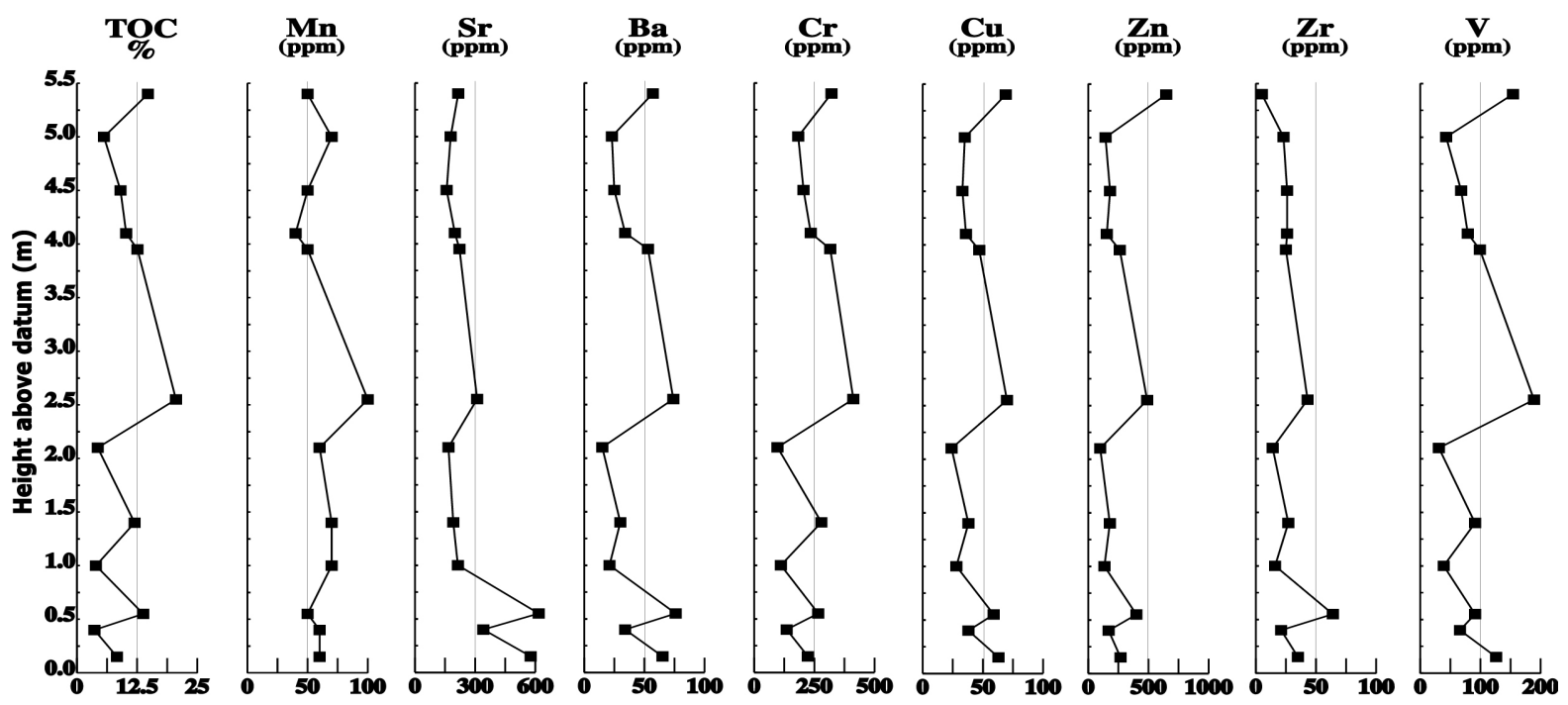

Figure 9. Depth profiles illustrate the distribution of minor elements. 
with that of TOC. Based on petrography results; calcite is mainly found as biogenic carbonate and Mg is mainly from dolomite. Productivity indicators (e.g. $\mathrm{P}_{2} \mathrm{O}_{5}$ ) in addition to that of sulfur (Figure 10) show positive distribution with that of TOC. $\mathrm{P}_{2} \mathrm{O}_{5}$ is reported to increase with increasing productivity ([8] [41] [42]). The good correlation between the sulfur distribution and TOC distribution indicates that the majority of sulfur in this section is related to OM and therefore the sulfur is organic in origin and not diagenetic. Similar results have been reported for some OS from the region (e.g. [43]). Clay and clastic input indicators profiles (e.g. $\mathrm{Al}_{2} \mathrm{O}_{3}$ ) reveal positive distribution with that of TOC. Such trend in these profiles is important in discussing the OS genesis. These indicators reported to be increase with clay input increase (e.g. [44] [45]).

With exception of Mn, almost all minor elements show quite similar distribution to that of TOC. Mn is considered as a redox sensitive. Low Mn indicates reduced bottom water. Mn content increases with the $\mathrm{O}_{2}$ increase in bottom water [44] [46]. Barium (Ba) and Chromium (Cr) increase with increase OM and productivity and oxygen depletion (e.g. [45] [47]). Strontium (Sr) is associated with carbonate and used as continental weathering indicator (e.g. [48]). Vanadium (V) is mainly associated with OM (e.g. [49]). Copper (Cu) and Zinc (Zn) are related to sulfides and OM and they increase with increased primary productivity (e.g. [45]). Overall, this section is quite rich in certain trace elements. The enrichment of Belqa Group sediments with trace elements has been attributed to direct precipitation from sea water (chemical precipitation and biogenic activity), especially sea water enriched with an exogenic metal flux leached from the Troodos and Baer Bassit ophiolites [50].

\subsection{Oil Shale Quality}

The quality of the OS within this horizon can be inferred from results of fisher assay analysis (Figure 11), in addition to that of total S\% determination that was performed on selected samples of different TOC contents (Figure 10). This section show different oil yielding capacities. As the OM content increases the oil yield increase. The moisture content is relatively low. The sulfur content is related to organic matter as discussed above. One positive point for this type of OS is that the total sulfur content in OS of this section is quite low compared with sulfur content of Maastrichtian OS types. The sulfur content in the Maastrichtian OS types is quite high and reaches nearly $5 \%$ wt [1]. Therefore, the OS of this type is considered as potential for future utilization.

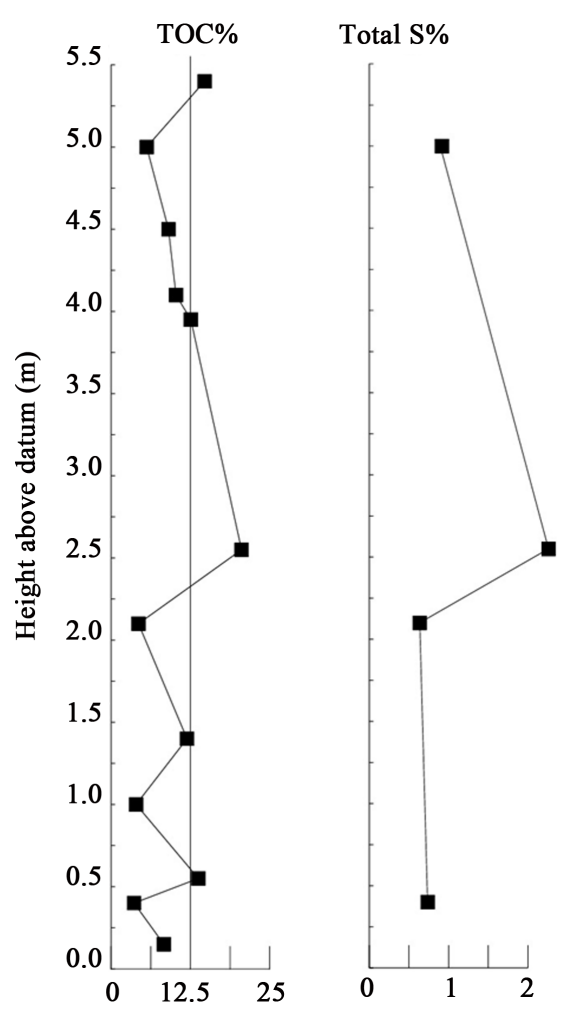

Figure 10. Depth profiles illustrate the distribution of S\% in four selected samples. 


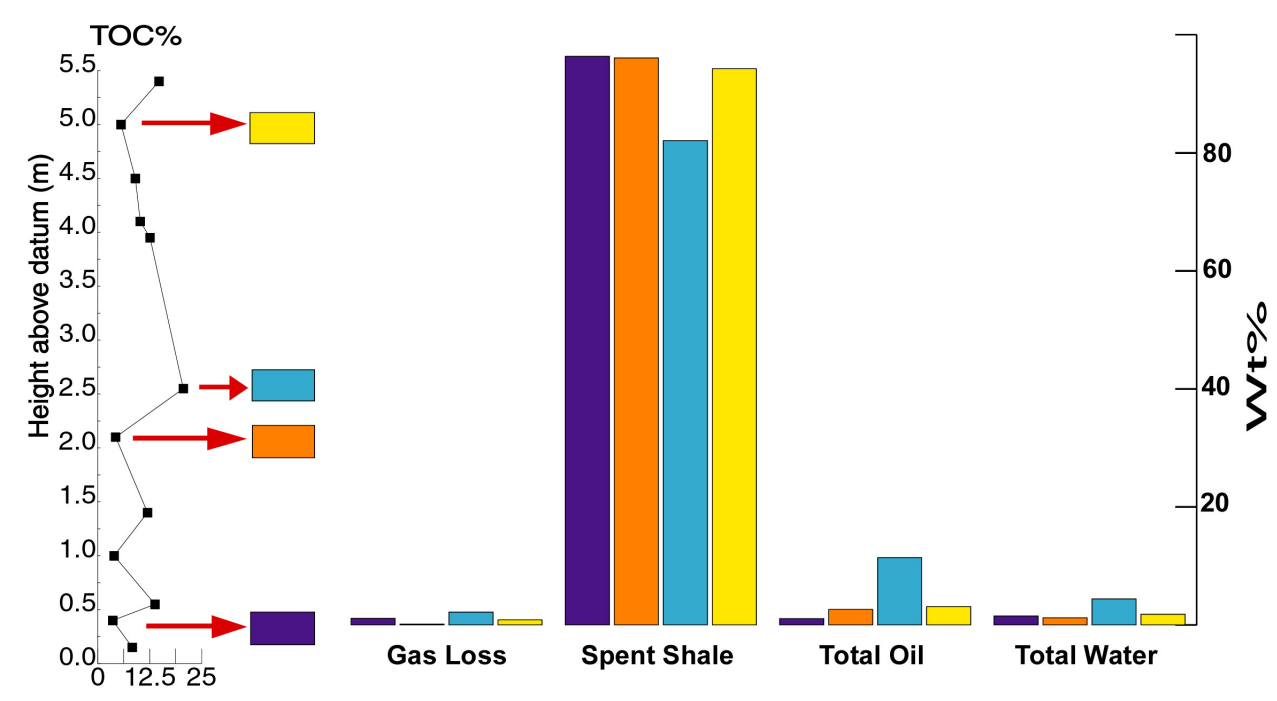

Figure 11. Fisher assay analysis results for selected OS samples.

\subsection{Oil Shale Genesis}

The lamination in TOC-rich bands may indicate low oxygen concentrations. This supported with the reduced concentration of Mn which has been used by Minster et al. [46] as redox sensitive indicator. Combination the results of petrography, mineralogy, and geochemistry discussed previously; data suggest that the OS has been formed during period of high productivity with increase of clastic input from the continental part. Bottom water conditions have fluctuated. Periods of reduced productivity with increase of bottom water oxygenation and OM oxidation might be existed. Dolomite in TOC-depleted bands was formed by replacement of calcite under variety of conditions. Dolomitization might take place in shallow, warm, restricted Mg-rich environment within the continental shelf of Tethys Ocean under favourable $\mathrm{pH}$, Eh, salinity, and temperature conditions. For the formation of dolomite, Mg might be supplied from overlying seawater, while calcium was supplied by the dissolution of calcium carbonate. The carbon was seemed to be supplied from carbonate dissolution and organic carbon oxidation. It can be suggested that under such conditions and with the availability of source materials; the dolomite has started to be originated. The rate of dolomite formation appears to be limited by the rate of calcium carbonate dissolution and organic matter oxidation.

\section{Conclusion}

Unlike oil shale from Maastrichtian to early Tertiary, this OS horizon is highly dolomitized. This OS type contains considerable content of OM. One economic potential for this types of OS is that the sulfur content is quite low compared with that of Maastrichtian OS types. This type of OS shows textural variations in both TOC-rich and TOC-depleted bands. The major rock component is dolomite with variable amounts of OM, calcite, quartz, and other minor minerals. Productivity indicators are positively distributed with OM. There is a negative correlation of organic matter content with carbonate content. The dolomite is diagenetic in origin and reveals complex diagenetic history and illustrates the importance of diagenetic alteration in the formation of this type of OS. The results of this study suggest that the formation of dolomite in this OS type appears to be limited by the rate of organic matter oxidation.

\section{Acknowledgements}

The authors are thankful for the NRA staff for their assistance during the lab work.

\section{References}

[1] Alali, J. and Sawaqed, S. (2006) Oil Shale Resources Development in Jordan. Unpublished Report. Natural Resources Authority, Amman. 
[2] Abed, A.M. (2000) The Geology of Jordan and Its Environment and Water (in Arabic). Publication of the Jordanian Geologists Association, Amman.

[3] Abed, A.M., Arouri, K., Amiereh, B.S. and Al-Hawari, Z. (2009) Characterization and Genesis of Some Jordanian Oil Shales. Dirasat, Pure Sciences, 36, 7-17

[4] Abed, A.M., Al-Arouri, K. and Boreham, C.J. (2005) Source Rock Potential of the Phosphorite Bituminous ChalkMarl Sequence in Jordan. Marine and Petroleum Geology, 22, 413-425. http://dx.doi.org/10.1016/j.marpetgeo.2004.12.004

[5] Abed, A.M. and Arouri, K. (2006) Characterization and Genesis of Oil Shales from Jordan. International Conference on Oils Shale: "Recent Trends in Oil Shale", 7-9 November 2006, Amman, PAPER No. Rtos-A121.

[6] Abed, A.M. and Al-Arouri, K. (1994) Organic Geochemistry of Central Jordan Upper Cretaceous Phosphorites: Phosphogenesis and Source Rock. Proceedings of the 2nd International Conference-Geology of the Arab World, Cairo University, Cairo, 321-338

[7] Abed, A.M. and Amireh, B.S. (1983) Petrography and Geochemistry of Some Jordanian oil Shales from North Jordan. Journal of Petroleum Geology, 5, 261-274. http://dx.doi.org/10.1111/j.1747-5457.1983.tb00571.x

[8] Alnawafleh, H.M. (2007) Geological Factors Controlling the Variability of Maastrichtian Bituminous Rocks in Jordan. PhD Thesis, The University of Nottingham, Nottingham.

[9] Alnawafleh, H. and Fraige, F. (2013) Characterization of South and Central Jordan Oil Shales. European Journal of Scientific Research, 102, 589-595

[10] Alnawafleh, H.M. and Fraige, F.Y. (2015) Analysis of Selected Oil Shale Samples from El-Lajjun, Central Jordan. Geomaterials, 5, 77-84. http://dx.doi.org/10.4236/gm.2015.53008

[11] Dercourt, J., Gaetani, M., Vrielynck, B., Barrier, E., Biju-Duval, B., Brunet, M.F., Cadet, J.P., Crasquin, S. and Sandulescu, M., Eds. (2000) Atlas Peri-Tethys, Palaeogeographical Maps. 24 Maps and Explanatory Notes: 1-XX, CCGM/ CGMW, Paris, 1-269.

[12] Abed, A.M. (1994) Shallow Marine Phosphorite-Chert-Palygorskite Association, Late Cretaceous, Amman Formation, Jordan. In: Iijima, A., Abed, A.M. and Garrison, R., Eds., Siliceous, Phosphatic and Glauconitic Sediments of the Tertiary and Mesozoic, VSP, Zeist, 205-324.

[13] Abu-Jaber, N., Jawad Ali, A. and Shinaq, R. (1997) Genesis of the Amman Formation Silicified Limestone of Jordan. Africa Geoscience Review, 4, 381-393.

[14] Abu Saad, L. and Al Bashish, M. (1999) Surface and Subsurface Lithostratigraphic Relationships of the Cretaceous Amman Silicified Limestone Formation (Belqa Group) in Jordan. Subsurface Geology Bulletin, No. 10, The Hashemite Kingdom of Jordan, Ministry of Energy and Mineral Resources, Natural Resources Authority, Amman, 58 p.

[15] Powell, J.H. (1989) Stratigraphy and Sedimentation of the Phanerozoic Rocks in Central and South Jordan-Part B: Kurnub, Ajlun and Belqa Groups. Geological Bulletin, No. 11, The Hashemite Kingdom of Jordan, Ministry of Energy and Mineral Resources, Natural Resources Authority, Amman, 130 p.

[16] Alonso-Zarza, A.M. and Martín-Pérez, A. (2008) Dolomite in Caves: Recent Dolomite Formation in Oxic, Non-Sulfate Environments. Castañar Cave, Spain. Sedimentary Geology, 205, 160-164. http://dx.doi.org/10.1016/j.sedgeo.2008.02.006

[17] Al-Awadi, M., Clark, W.J., Moore, W.R., Herron, M., Zhang, T., Zhao, W., Hurley, N., Kho, D., Montaron, B. and Sadooni, F. (2009) Dolomite: Perspectives on a Perplexing Mineral. Oilfield Review, 21, 32-45.

[18] Pichler, T. and Humphrey, J.D. (2001) Formation of Dolomite in Recent Island-Arc Sediments Due to Gas-SeawaterSediment Interaction. Journal of Sedimentary Research, 71, 394-399. http://dx.doi.org/10.1306/2DC4094D-0E47-11D7-8643000102C1865D

[19] Madanat, M. and Al-Omari, Y. (2006) Mineral Status and Future Opportunity: Dolomite. Geological Survey Administration. Unpublished Report, The NRA, Amman. http://www.nra.gov.jo/images/stories/pdf_files/Dolomite.pdf

[20] Abed, A.M. and Kraishan, G.M. (1991) Evidence for Shallow-Marine Origin of a "Monterey-Formation Type” ChertPhosphorite-Dolomite Sequence: Amman Formation (Late Cretaceous), Central Jordan. Facies, 24, 25-38. http://dx.doi.org/10.1007/BF02536839

[21] Al-Mehdawi, H.S. (2000) Petrography, Geochemistry and Evaluation of Organic Matter of Oil Shale in the Area between Wadi Zahar and Wadi Abu-Ziyad (NW Jordan). Unpublished Master's Thesis, Yarmouk University, Irbid.

[22] Amireh, B.S. (1979) Geochemistry and Petrography of Some Jordanian Oil Shales. Unpublished Master's Thesis, The University of Jordan, Amman.

[23] Hufnagel, H. (1980) Investigation of the El-Lajjun Oil Shale Deposit, Bundesanstalt fur Geowissenschaften und Rohstoffe, Hannover. Technical Cooperation Project No. 78.2156.5. 
[24] Hufnagel, H., Schmitz, H.H. and El-Kaysi, K. (1980) Investigation of the El Lajjun Oil Shale Deposits. Unpublished Report, NRA, Amman.

[25] Jarrar, M. and Mustafa, H. (1995) Mineralogical and Geochemical Study of the Oil Shale of Wadi Esh-Shallala (NJordan). Abhath Al-Yarmouk. Pure Science and Engineering Series, 4, 111-136.

[26] Jarrar, M.N. (1989) Composition, Stratigraphy and Depositional Environment of Kerogeneous Limestone of Wadi EshShallalla (NW Jordan). Unpublished Master's Thesis, Yarmouk University, Irbid.

[27] Ali Hussein, M., Alqudah, M., van den Boorn, S., Kolonic, S., Podlaha, O.G. and Mutterlose, J. (2014) Eocene Oil Shales from Jordan-Their Petrography, Carbon and Oxygen Stable Isotopes. GeoArabia, 19, 139-162.

[28] Ali Hussein, M., Alqudah, M., Podlaha, O.G., Blessenohl, M. and Mutterlose, J. (2015) Depositional Environment of Late Cretaceous to Eocene Organic-Rich Marls from Jordan. GeoArabia, 20, 191-210.

[29] Alqudah, M., Ali Hussein, M., Podlaha, O.G., van den Boorn, S., Kolonic, S. and Mutterlose, J. (2014) Calcareous Nannofossil Biostratigraphy of Eocene Oil Shales from Central Jordan. GeoArabia, 19, 117-140.

[30] Alqudah, M., Ali Hussein, M., Van den Boorn, S., Giraldo, V., Kolonic, S., Podlaha, O.G. and Mutterlose, J. (2014) Eocene Oil Shales from Jordan-Paleoenvironmental Implications from Reworked Microfossils. Marine and Petroleum Geology, 52, 93-106. http://dx.doi.org/10.1016/j.marpetgeo.2014.02.001

[31] Alqudah, M., Ali Hussein, M., Van den Boorn, S., Podlaha, O.G. and Mutterlose, J. (2015) Biostratigraphy and Depositional Setting of Maastrichtian e Eocene Oil Shales from Jordan. Marine and Petroleum Geology, 60, 87-104. http://dx.doi.org/10.1016/j.marpetgeo.2014.07.025

[32] Bowen, R. and Jux, U. (1987) Afro-Arabian Geology. Chapman and Hall, London.

[33] Chaimaov, T.A., Barazangi, M., Al-Saad, D., Sawaf, T. and Gebran, A. (1992) Mesozoic and Cenozoic Deformation Inferred from Seismic Stratigraphy in the Southwestern Intracontinental Palmyride Fold-Thrust Belt, Syria. Geological Society of America Bulletin, 104, 704-715. http://dx.doi.org/10.1130/0016-7606(1992)104<0704:MACDIF>2.3.CO;2

[34] Almogi-Labin, A., Bein, A. and Sass, E. (1993) Late Cretaceous Upwelling System along the Southern Tethys Margin: Interrelationship between Productivity, Bottom Water Environments, and Organic Matter Preservation. Paleoceanography, 8, 671-690. http://dx.doi.org/10.1029/93PA02197

[35] Khoury, H.N. (2015) Uranium Minerals of Central Jordan. Applied Earth Science, 124, 104-128. http://dx.doi.org/10.1179/1743275815Y.0000000005

[36] Barjous, M.O. (1992) The Geology of the Ash Shawbak Area. Map Sheet No. 3151 III, Bulletin 19, Natural Resources Authority, Amman.

[37] Peters, K.E., Walters, C.C. and Moldowan, J.M. (2005) The Biomarker Guide, Part II: Biomarkers and Isotopes in Petroleum Exploration and Earth History. Cambridge University Press, Cambridge.

[38] Minster, T., Yoffe, O., Nathan, Y. and Flexer, A. (1997) Geochemistry, Mineralogy and Paleoenvironments of Deposition of the Oil Shale Member in the Negev. IJES, 46, 41-59.

[39] Dill, H.G., Kus, J., Abed, A.M., Sachsenhofer, R.F. and Abul Khair, H. (2009) Diagenetic and Epigenetic Alteration of Cretaceous to Paleogene Organic-Rich Sedimentary Successions in North-Western Jordan, Typical of the Western Margin of the Arabian Plate. GeoArabia, 14, 101-140.

[40] Soudry, D. (2000) Carbonate-Phosphate Competition in the Negev Phosphorites: A Microstructural Study. In: Glenn, C.R., Prevot-Lucas, L. and Lucas, J., Eds., Marine Authigenesis: From Global to Microbial, SEPM Special Publication No. 66, SEPM (Society for Sedimentary Geology), Oklahoma, 415-426.

[41] Cappellen, P.V. (2003) Biomineralization and Global Biogeochemical Cycles. Reviews in Mineralogy and Geochemistry, 54, 357-381. http://dx.doi.org/10.2113/0540357

[42] Minster, T. (2001) Significance of $\mathrm{P}_{2} \mathrm{O}_{5}$ Distribution in the Oil Shale Member, Gareb Formation, Mishor Rotem and Oron Basins. GSI-Current Research, 13, 47-51.

[43] Minster, T., Nathan, Y. and Raveh, A. (1992) Carbon and Sulfur Relationships in Marine Senonian Organic-Rich, IronPoor Sediments-A Case Study. Chemical Geology, 97, 145-161. http://dx.doi.org/10.1016/0009-2541(92)90141-Q

[44] Sangiorgi, F., Dinelli, E., Maffioli, P., Capotondi, L., Giunta, S., Morigi, C., Principato, M.S., Negri, A., Emeis, K.C. and Corselli, C. (2006) Geochemical and Micropaleontological Characterisation of a Mediterranean Sapropel S5: A Case Study from Core BAN89GC09 (South of Crete). Palaeogeography, Palaeoclimatology, Palaeoecology, 235, 192207. http://dx.doi.org/10.1016/j.palaeo.2005.09.029

[45] Stuben, D., Kramar, U., Berner, Z., Stinnesbeck, W., Keller, G. and Adatte, T. (2002) Trace Elements, Stable Isotopes, and Clay Mineralogy of the Elles II K-T Boundary Section in Tunisia: Indications for Sea Level Fluctuations and Primary Productivity. Palaeogeography, Palaeoclimatology, Palaeoecology, 178, 321-345.

http://dx.doi.org/10.1016/S0031-0182(01)00401-1 
[46] Minster, T., Ilani, S. and Yoffe, O. (1997) Manganese as an Indicator of the Intensity of Anoxia during the Deposition of the Senonian Oil Shales in the Negev. Oil Shale, 40, 5-18.

[47] Martinez-Ruiz, F., Paytan, A., Kastner, M., Gonzalez-Donoso, J.M., Linares, D., Bernasconi, S.M. and Jimenez-Espejo, F.J. (2003) A Comparative Study of the Geochemical and Mineralogical Characteristics of the S1 Sapropel in the Western and Eastern Mediterranean. Palaeogeography, Palaeoclimatology, Palaeoecology, 190, 23-37. http://dx.doi.org/10.1016/S0031-0182(02)00597-7

[48] Stoll, H.M. and Schrag, D.P. (2001) Sr/Ca Variations in Cretaceous Carbonates: Relation to Productivity and Sea Level Changes. Palaeogeography, Palaeoclimatology, Palaeoecology, 168, 311-336. http://dx.doi.org/10.1016/S0031-0182(01)00205-X

[49] Bellanca, A., Erba, E., Neri, R., Premoli Silva, I., Sprovieri, M., Tremolada, F. and Verga, D. (2002) Palaeoceanographic Significance of the Tethyan "Livello Selli” (Early Aptian) from the Hybla Formation, Northwestern Sicily: Biostratigraphy and High-Resolution Chemostratigraphic Records. Palaeogeography, Palaeoclimatology, Palaeoecology, 185, 175-196. http://dx.doi.org/10.1016/S0031-0182(02)00299-7

[50] Fleurance, S., Cuney, M., Malartre, M. and Reyx, J. (2013) Origin of the Extreme Polymetallic Enrichment (Cd, Cr, Mo, Ni, U, V, Zn) of the Late Cretaceous-Early Tertiary Belqa Group, Central Jordan. Palaeogeography, Palaeoclimatology, Palaeoecology, 369, 201-219. http://dx.doi.org/10.1016/j.palaeo.2012.10.020 